\title{
An Analysis of Second Cultural Introduction for Non-English Majors Based on Intercultural Communication
}

\author{
Qian Ma \\ School of Foreign Languages, Wuhan University of Technology, Wuhan 430070, China. \\ 2066328858@qq.com
}

Keywords: Language and Culture, Cultural Introduction, Interculture, College English Teaching.

\begin{abstract}
Under the background of globalization, intercultural communication has penetrated into our lives. More and more scholars have begun to pay attention to the research and application of intercultural communication and its related fields. This paper, based on the study of the relationship between language and culture, will analyze the advantages and disadvantages of the introduction of the second culture. What are the problems of cultural introduction? How should we do to solve them? To thoroughly answer the question, this study conducted a questionnaire survey to 200 Non-English Majors of Wuhan University of Technology. The data obtained in the survey can reflect the Non-English Majors' attitudes toward English culture and Chinese culture. Finally, the paper will analyzes the main reasons and give several suggestions related to the introduction of culture into college English teaching in China.
\end{abstract}

\section{Introduction}

Language is the most important communication tool for human beings. Due to the historical background, geographical location and customs of different nationalities, there are no two cultures can be the same. The emerging intercultural communication failures show that communication cannot be effective, if one only "know" a language, but doesn't "understand" the cultural connotation of the language. Spair, an American linguist, pointed out in 1921 that language cannot exist without culture. [1] In the book The Principles of Language Teaching and Learning, Brown clearly states: "Language is a part of culture, and culture is part of the language. Once they are separated, they lose their meaning".[2] Winston Brembeck, an expert on foreign language teaching in the United States, once said, "It is the best way to develop a fluent fool that adopting a teaching method which teaches language without the understanding of its culture".[3] Second cultural teaching in China is relatively late. In 1950s, some scholars noticed the relationship between language and culture, but because of some social factors, it did not cause a big impact. In 1970s, intercultural communication become increasingly frequent with the development of the world economy. Facing to the emerging phenomenon of "cultural conflict" and "culture shock", people began to realize the disadvantages of teaching language without the understanding of its culture. Language and culture is an indivisible whole. Only by interpreting a language in the cultural environment, can we master the language more accurately and appropriately. So, in the process of teaching and learning a language, we must pay more attention to the corresponding culture.

\section{Analysis of the Advantages and Disadvantages of Cultural Second Introduction}

\subsection{Second Cultural Acquisition Influences Second Language Acquisition}

The generation of language meaning cannot be separated from the specific cultural background. The process of language communication is not only a interpretation of the system of language symbols, but also a interpretation of the cultural connotations behind the language. Cultural acquisition and language acquisition are interactive but relatively independent.

Sapir-Whorf theory holds that language determines people's way of thinking, and speaking a foreign language means changing cultural perspective.[4] The second cultural acquisition of learners 
has a direct impact on their acquisition of the second language, the greater the degree of understanding of the culture, the faster they can learn the second language. On the contrary, learners' exclusion of the culture will be the biggest obstacle to the acquisition of the second language. Introducing English culture to learners is helpful to reduce their thinking sets and language habits formed by the Chinese culture. In this way, we'll provide learners a premise of further contact of the second language..

\subsection{Second Cultural Introduction Leads to Cultural Conflict}

J.Fiske pointed out that "culture is not a relatively harmonious and stable system of meaning, but a conflict between different (and sometimes even antagonistic) social and cultural groups. The process of interpretation is also a process of cultural reflection, which is a potential social struggle. It is a process of redefining the language by different social groups for their own interests". [5] The introduction of culture into foreign language teaching must be a dynamic process of interaction between different societies and cultures. This process directly affects the learners' enthusiasm for foreign language learning and the development of foreign language teaching.

Before touching the second culture, learners already has a complete set of system of their first culture. They has formed its own ingrained thinking mode, behavior and habits etc.. When facing the conflict between the two cultures, part of the learners may appear different degree of confusion and conflict, which will become the key factors affecting their foreign language learning, and even their own world outlook on life. On the other hand, some educators and learners over emphasize the acceptance of the target language culture. As a result, a thought which chasing foreign culture and denying the value of the national culture blindly is spreading in the society. Now, the national culture in a marginal position in English teaching. Although this is not the intentions of the educators, it makes the English teaching, to a certain extent, a potential language tool for the "cultural erosion" of western.

\section{The Current Situation and Problems of Second Cultural Introduction}

Language and culture should be combined in foreign language teaching. A questionnaire survey was conducted among 200 non-English Majors in Wuhan University of Technology, However, According to the analysis of the 168 questionnaire which is valid, it is found that there is still a gap between the language and culture in English teaching.

Table 1. Part of the questions and data (percentage retained integers)

\begin{tabular}{|c|c|c|c|}
\hline $\begin{array}{c}\text { Q9: Are you interested in English } \\
\text { culture? }\end{array}$ & Very much $32 \%$ & Average $60 \%$ & No $7 \%$ \\
\hline $\begin{array}{l}\text { Q10: Which does you prefer, Chinese } \\
\text { or English culture? }\end{array}$ & Chinese culture $49 \%$ & English culture $13 \%$ & As long as useful $39 \%$ \\
\hline $\begin{array}{l}\text { Q11:Do you want to learn Chinese } \\
\text { traditional culture? }\end{array}$ & Very much $20 \%$ & Average $70 \%$ & No $10 \%$ \\
\hline $\begin{array}{l}\text { Q12:Did you take the initiative to learn } \\
\text { Chinese traditional culture? }\end{array}$ & Often $17 \%$ & Sometimes $57 \%$ & Little or no $27 \%$ \\
\hline $\begin{array}{l}\text { Q14: Traditional culture for the current } \\
\text { college students is...? }\end{array}$ & Very important 54\% & Slightly useful $42 \%$ & Dispensable $4 \%$ \\
\hline $\begin{array}{l}\text { Q15:What do you think of the situation } \\
\text { of traditional culture? }\end{array}$ & Still important $27 \%$ & Difficult to judge $28 \%$ & Gradually disappear $42 \%$ \\
\hline $\begin{array}{l}\text { Q16: Where did you learn the Chinese } \\
\text { culture? }\end{array}$ & Social life $68 \%$ & Classroom $32 \%$ & \\
\hline $\begin{array}{l}\text { Q18:Are you willing to inherit and } \\
\text { develop Chinese traditional culture? }\end{array}$ & Very much $53 \%$ & $\begin{array}{l}\text { Yes, but it is not } \\
\text { practical } 40 \%\end{array}$ & Don't care $7 \%$ \\
\hline
\end{tabular}

\subsection{Learners' awareness of Cultural Acquisition is Weak}

According to Q9 and Q11, most of the students are not interested in culture, neither Chinese nor English. It indicates that the learners' awareness of cultural acquisition is very weak. For a long period, English teaching method of China mainly is the traditional grammar-translation method. In the class, teachers spend a lot of time to analyze the word and grammar, and students are only accept passively. In the present, people have a clearer understanding of the relationship between second cultural introduction and second language teaching. Scholars claim that we should pay more attention to the 
cultivation of students' cultural awareness and intercultural communicative competence in English teaching. However, the traditional concept of learning and teaching still exist in both learners and educators.

\subsection{Wrong Learning Attitudes Around the Society}

$39 \%$ of the students in the Q10 think that that as long as useful, it does not matter what kind of culture they learn. Q18 shows that about $40 \%$ of the students are willing to inherit the Chinese culture, but they thought that Chinese culture is not practical. To some extent, this reflects the concepts of "pragmatism" and "culture is useless" among our society. The method of English achievement assessment is test. Although the educators add some content related to culture in the test, almost all the kinds of tests still take listening, speaking, reading and writing as the core standard. The standard of English assessment and the blind worship for various foreign language certificates lead to a wrong learning attitudes. Educators and learners pay more attention to the basic linguistic skills. Learning is score, and the Chinese and English cultures which seemingly unhelpful to improve scores is unwanted.

\subsection{The Lack of Chinese Traditional Culture Education}

Although the questionnaire in Q12, Q14 and Q16 show that most learners think that the traditional culture still play an important role among college students, only $17 \%$ of learners have learned Chinese traditional culture imitatively. Besides, only $32 \%$ of them have learned Chinese culture from class. There maybe two reasons. First, learners' awareness of cultural acquisition is weak. Second, most English educators think that learning English is just learning knowledge about English. So, in the English teaching, whether in textbooks or in the class, Chinese culture is excluded. However, this approach has many drawbacks. On one hand, one-fold culture teaching dissevers the relationship between Chinese and English culture, limits the cultural views of the students, and do harm to the cultivation of intercultural awareness of students. On the other hand, ignoring Chinese traditional culture education and publicizing English culture excessively will weaken the learners' awareness of Chinese traditional culture. Q15 shows that $42 \%$ of the learners think that the traditional culture is disappearing.

It can be seen that the introduction of second culture in College English teaching is not ideal.

\section{Suggestions on the Introduction of Second Culture}

\subsection{Change the Mode of Thinking and Improve the Traditional Teaching Methods}

Language teaching and culture teaching must be organically combined. The traditional teaching methods cannot meet the needs of today's teaching goals. In 2007, the Ministry of Education promulgated the College English curriculum requirements listed cultural teaching as one of the contents in College English teaching. College English curriculum is not only a curriculum of language, but also a curriculum to help student to broaden their knowledge and understanding of the world culture. [6] In the college English teaching, first, teachers should guide the students to change their single thinking mode and to avoid understanding the target language and culture in their native system of language and culture. Second, teachers should enhance students' cultural awareness and tolerance by using cultural comparison. Third, teachers should pay attention to the particularity of the students, and select the appropriate content to teach. Finally, teachers should put the cultural content naturally into English teaching, so that students can understand it quickly and appropriately.

\subsection{Grasp the Intensity of Second Cultural Introduction}

Wind Dowson said: "communication is two-way, but not one-way. Communication means to absorb and spread, both are indispensable."[7] In English teaching, it is necessary to absorb the essence of foreign culture, but also to maintain the essence of the national culture. Therefore, educators should appropriately increase the content of Chinese culture in college English teaching materials. Where conditions permit, the school should carry out cultural curriculum which includes the two kinds of cultures, rather than foreign culture or Chinese culture course single. The organic integration of the two cultures will enhance cultural contrast, and effectively improve the intercultural perception and cultural criticism of students. For our learners, the purpose of English learning is not only to 
understand the western society and culture, but also to carry forward the historical task of spreading and developing Chinese culture.

\subsection{Advocate "interculture" in College English Teaching}

It is not conducive to learning, if the distance between learners and the native culture or between learners and the target language is too close or too much. Which is helpful to the second language learning is to maintain a certain distance with both the first and the second culture. [8] Therefore, "interculture" is a necessary way for English teaching. In the domestic academic circles, Wang Jianqin first put forward the concept. He pointed out that "the system of intercultural behavior" refers to a unique cultural system of second language learners, or refers to the second language learners' speech act system with intercultural characteristics. [9] Gu Jiazu believes that "interculture" is a process of second language acquisition. He put forward the hypothesis of "cultural critical period". [10] In English teaching, educators should recognize and advocate the concept of "interculture". They should point out that cultural acquisition is not a choice between the two cultures to reduce the learner's psychological pressure. They should encourage learners to form their own "interculture", find a balance between the two cultures, and handle the various kinds of problems appeared in intercultural communication flexibly.

\section{Conclusion}

Through in-depth study of the relationship between language and culture, more and more people realize that we can' t convey and understand the correct language meaning without a certain cultural background. The importance of cultural introduction in college English teaching is self-evident. Second cultural Introduction has both advantages and disadvantages. The intensity of second cultural introduction directly affects the development of the college English teaching and even the whole social culture. So, educators must avoid "excessive" and "inadequate" in the process, create a harmonious development of the two cultures, and guide learners to combine the two cultures, eventually form their own "interculture".

\section{Acknowledgments}

This Paper is supported by the Fundamental Research Funds for the Central Universities Project No.:175217008

\section{References}

[1] Edward Sapir. Language:An Introduction to the Study of Speech [M].New York:Harcourt, Brace \& Co,1921.221.

[2] Brown, H. D. Principles of Language Learning and Teaching ( $3 r d$ edn.). Englewood Cliffs, NJ: Prentice Hall Regents. 1994. 165.

[3] Luo Changpei. Language and Culture [M]. Beijing: Language \& Culture Press, 1989, P10-24.

[4] Carrol, J.B.(ed.) Language, Thought and Reality: Selected Writings of Benjamin Lee Whorf [M]. Massachusetts: M.I.T. Press, 1956. P134-159.

[5] Fiske, John. Interpreting Popular Culture [M]. Boston University Press, 1989. P34.

[6] Higher Education Department of the Ministry of Education.College English Curriculum Requirements [M]. Shanghai: Shanghai Foreign Language Education Press, 2007. P7.

[7] Widdowson, G. Aspects of the Relationship Between Culture and Language. [M] Paris: Didier-Erudition, 1991. P102-105.

[8] Bi Jiwan. Interculture Communication and Second Language Teaching [M]. Beijing: Beijing Language and Culture University Press, 2009. P507.

[9] Wang Jianqin. A New Dimension of Intercultural Research: the Intercultural Behavior System of Learners [J]. Beijing: Chinese Teaching In The World, 1995, (3): 38-49. 
[10] Gu Jiazu, Lu Sheng. Language and Culture [M]. Shanghai: Shanghai Foreign Language Education Press, 2002, P147-149. 